\title{
THE INFLUENCE OF HALLUX VALGUS ON PELVIS AND LOWER EXTREMITY MOVEMENT DURING GAIT
}

\author{
Jitka Kozáková, Miroslav Janura, Zdeněk Svoboda, Milan Elfmark, Miloslav Klugar*
}

\author{
Faculty of Physical Culture, Palacký University, Olomouc, Czech Republic \\ * Faculty of Medicine and Dentistry, Palacký University, Olomouc, Czech Republic
}

Submitted in November, 2011

BACKGROUND: The hallux and the first metatarsophalangeal joint play a major role in load transmission during walking.

OBJECTIVE: The main aim of this study was to investigate differences in kinematics of the pelvis and lower extremities during gait by comparing people with hallux valgus (HV) and a control group (CG).

METHODS: We compared subjects with asymptomatic bilateral HV $(\mathrm{n}=6,57.8 \pm 5.64$ years $)$ with those who had CG $(n=11,50.7 \pm 4.41$ years). Gait analysis was investigated using an optoelectronic system Vicon MX. The subjects walked at self selected speeds. In total, five trials of each subject were analyzed. The statistical processing was performed by means of the Student t-test. The effect size was determined using the $\omega^{2}$ measure.

RESULTS: In people with HV there was a significantly smaller maximum of dorsal flexion during the stance phase $\left(\mathrm{p}<0.01, \omega^{2}>0.06\right)$ and a greater maximum of plantar flexion at the beginning of the stance phase $\left(\mathrm{p}<0.01, \omega^{2}\right.$ $>0.06)$. The maximum of knee extension at the end of the swing phase was significantly greater $\left(p<0.01, \omega^{2}>0.06\right)$ in subjects with HV. In the frontal plane, a significantly smaller maximum of hip abduction $\left(p<0.01, \omega^{2}>0.06\right)$ during the gait cycle was observed in people with HV. The range of pelvic obliquity $\left(p<0.01, \omega^{2}>0.06\right)$ and pelvic rotation $\left(\mathrm{p}<0.01, \omega^{2}>0.06\right)$ were significantly smaller in people with HV.

CONCLUSION: This study demonstrated that HV does not exclusively concern the foot. The valgus deformity of the big toe can negatively influence function of the lower extremities and can cause overloading of those segments as well.

Keywords: Hallux valgus, gait, kinematic analysis.

\section{INTRODUCTION}

Hallux valgus (HV) is a complex, progressive triplanar forefoot deformity. It incorporates a valgus deviation of the big toe, increased varus of the first metatarsal bone and a medial prominence of its head (Lorimer, Neale, \& French, 2006). This is related to other foot problems, depending on the cause, duration of symptoms and the degree of deformity. HV deformity usually occurs together with a decrease of the transverse arch, an occurrence of hammer toes, a widening of the forefoot and pressure distribution changes under metatarsal heads, causing a metatarsalgia (Halebian \& Gaines, 1983; Torkki, 2004).

$\mathrm{HV}$ deformity is related to foot dysfunction and may lead to failure of basal support in the stance phase, shock absorption and load transmission during gait. The structure and function of the foot play the main role in postural dynamics. Stabilization of the first metatarsal is the basic precondition for optimal foot function. In hallux valgus deformity, first ray dynamic stabilization failure and loss of the contact between the first metatarsophalangeal joint surfaces and sesamoid bones is typical (Lorimer et al., 2006). HV is related to functional joint centration failure in terms of postural ontogenesis (Kolář, 2001). Due to a chain failure, one dysfunctioning segment can cause overloading of other segments and change the movement pattern (Kučera, 1994; Vařeka \& Vařeková, 2003).

There are many studies analyzing the dynamic parameters of gait in people with HV (Blomgren, Turan, \& Agadir, 1991; Bryant, Tinley, \& Singer, 1999, 2000; Hughes, Clark, \& Klenerman, 1990; Martinez-Nova et al., 2010; Milani \& Retzlaff, 1995; Vittas, Jansen, \& Larsen, 1987; Waldecker, 2002, 2004; Yavuz et al., 2009), but only in a few studies were the kinematics of gait observed. HV was considered to be a static forefoot deformity. A multisegmental foot model for the purpose of 3D gait analysis is reported to demonstrate both decreased plantar and dorsal flexion in people with HV (Hwang, Choi, Lee, \& Kim, 2006). In subjects with juvenile $\mathrm{HV}$, greater hip flexion, greater knee flexion during swing phase, lesser knee extension and greater plantar flexion at the beginning of the stance phase were found (Janura, Cabell, Svoboda, Kozáková, \& Gregorková, 2008). 
The main aim of this study was to investigate the differences in the kinematics of the pelvis and the lower extremities during gait between people with $\mathrm{HV}$ and control group.

\section{MATERIAL AND METHODS}

The experimental group consisted of subjects with an asymptomatic bilateral HV deformity $(n=6$, age $=57.8 \pm 5.64$ years, height $=1.69 \pm 0.1 \mathrm{~m}$, weight $=$ $65.8 \pm 7.82 \mathrm{~kg}$ ). The control group (CG) included subjects $(\mathrm{n}=11$, age $=50.7 \pm 4.41$ years, high $=$ $1.73 \pm 0.06 \mathrm{~m}$, weight $=74.6 \pm 8.63 \mathrm{~kg}$ ) without any foot deformity nor problems affecting gait.

Using a 3D motion analysis system (Vicon MX, Oxford Metrics Inc., Oxford), movement of the pelvis and lower extremity segments was observed during gait. We used the Plug-In Gait model (7 segments, 16 reflex markers).

The advanced Vicon system with 7 infrared cameras was synchronized with 2 force platforms (Kistler 9286AA, Kistler Instrumente AG Winterthur, Switzerland). It enabled us to detect the phases of the gait cycle.

We carried out a kinesiology examination prior to the actual measurement. The subjects walked at self selected speeds without shoes. After two test trials, ten trials were measured. Five trials of each subject were analyzed - the ankle peaks in the sagittal plane (plantar/ dorsal flexion); knee peaks in the sagittal (flexion/extension) and frontal plane (varus/valgus); hip peaks in the sagittal (flexion/extension) and frontal plane (adduction/abduction); range of the pelvis movement in the sagittal (pelvis tilt); frontal (pelvis obliquity) and transverse plane (pelvis rotation) were quantified and evaluated by means of the Vicon Nexus 1.0 and Polygon Authoring Tools.

Collected data were analyzed by means of the Student t-test (Statistica 9.0, StatSoft, Inc.). The statistical significance level was set as 0.05 . Moreover, the omegasquared $\left(\omega^{2}\right)$ quantity was determined to be a measure of the effect size. A "rule of thumb" was employed if it was greater than 0.01 as a small effect, greater than 0.06 as a medium effect and greater than 0.15 as a big effect (Cohen, 1988).

\section{RESULTS}

The mean values and the standard deviations of measured variables in people with $\mathrm{HV}$ compared to $\mathrm{CG}$ are shown in TABLE 1 .

TABLE 1

Kinematic parameters of the gait in people with hallux valgus and the control group

\begin{tabular}{|l|c|c|c|c|c|c|}
\hline \multirow{2}{*}{$\begin{array}{l}\text { Group } \\
\text { Parameter }\end{array}$} & \multicolumn{2}{|c|}{ Hallux valgus } & \multicolumn{2}{c|}{ Control Group } & \multicolumn{2}{c|}{} \\
\cline { 2 - 7 } & Mean & SD & Mean & SD & \multicolumn{1}{c|}{ p } & $\boldsymbol{\omega}^{2}$ \\
\hline Dorsal flexion St & 15.09 & 5.6 & 18.1 & 5.22 & $\mathbf{0 . 0 0}$ & $\mathbf{0 . 0 6}$ \\
\hline Dorsal flexion Sw & 6.39 & 4.91 & 6.94 & 3.15 & 0.38 & 0.00 \\
\hline Plantar flexion St (LR) & 6.52 & 5.32 & 3.79 & 4.81 & $\mathbf{0 . 0 0}$ & $\mathbf{0 . 0 6}$ \\
\hline Plantar flexion St (PSW) & 14.46 & 8.22 & 15.33 & 6.82 & 0.46 & 0.00 \\
\hline Knee flexion St & 19.32 & 5.29 & 20.94 & 6.14 & 0.09 & 0.01 \\
\hline Knee flexion Sw & 62.86 & 2.7 & 62.43 & 6.5 & 0.62 & 0.00 \\
\hline Knee extension St & 7.27 & 3.09 & 6.78 & 3.76 & 0.39 & 0.00 \\
\hline Knee extension Sw & 4.76 & 2.4 & 2.46 & 3.47 & $\mathbf{0 . 0 0}$ & $\mathbf{0 . 1 1}$ \\
\hline Knee valgus & 0.1 & 5.61 & 4.07 & 8.81 & $\mathbf{0 . 0 0}$ & $\mathbf{0 . 0 5}$ \\
\hline Knee varus & 13.06 & 5.61 & 11.65 & 10.63 & 0.34 & 0.00 \\
\hline Hip flexion & 35.17 & 5.3 & 32.77 & 5.12 & $\mathbf{0 . 0 0}$ & $\mathbf{0 . 0 4}$ \\
\hline Hip extension & 6.05 & 5.35 & 8.92 & 6.91 & $\mathbf{0 . 0 1}$ & $\mathbf{0 . 0 4}$ \\
\hline Hip adduction & 9.04 & 4.38 & 8.16 & 4.49 & 0.22 & 0.00 \\
\hline Hip abduction & 2.87 & 3.72 & 5.49 & 3.96 & $\mathbf{0 . 0 0}$ & $\mathbf{0 . 0 9}$ \\
\hline Pelvic tilt & 2.91 & 0.78 & 3.43 & 1.12 & $\mathbf{0 . 0 2}$ & $\mathbf{0 . 0 5}$ \\
\hline Pelvic obliquity & 7.11 & 2.76 & 8.89 & 2.31 & $\mathbf{0 . 0 0}$ & $\mathbf{0 . 1 0}$ \\
\hline Pelvic rotation & 9.43 & 3.36 & 11.37 & 3.84 & $\mathbf{0 . 0 1}$ & $\mathbf{0 . 0 6}$ \\
\hline
\end{tabular}

Legend: SD - standard deviation; $p$ - level of statistical significance; $\omega_{2}$ - omega-squared; dorsal/plantar flexion - maximum of dorsal/ plantar flexion; knee flexion - maximum of knee flexion; knee extension - minimum of knee flexion; knee valgus/varus - maximum of knee valgus/varus; hip flexion/extension - maximum of knee flexion/extension; hip adduction - minimum of hip abduction, hip abduction, maximum of knee abduction, pelvic tilt/obliquity/rotation - range of pelvic tilt/obliquity/rotation; St - stance phase; Sw - swing phase; LR - loading response; PSW - pre-swing; all values were measured in degrees 
In people with $\mathrm{HV}$, a significantly greater maximum of plantar flexion during the loading response $\left(\mathrm{p}<0.01, \omega^{2}>0.06\right)$ and a smaller maximum of the dorsal flexion during midstance $\left(\mathrm{p}<0.01, \omega^{2}>0.06\right)$ were found (Fig. 1). Maximal knee extension at the end of the swing phase was significantly greater $(p<0.01$, $\omega^{2}>0.06$ ) in subjects with HV (Fig. 2). In the frontal plane, a significantly smaller maximum of hip abduction $\left(p<0.01, \omega^{2}>0.06\right)$ during the gait cycle was observed in people with HV (Fig. 3). The range of pelvic obliquity ( $\mathrm{p}<0.01, \omega^{2}>0.06$ ) (Fig. 4) and pelvic rotation $\left(p<0.01, \omega^{2}>0.06\right)$ were significantly smaller in people with HV.

\section{Fig. 1}

Ankle movement in the sagittal plane during gait in people with hallux valgus and the control group



Fig. 2

Knee movement in the sagittal plane during gait in people with hallux valgus and the control group

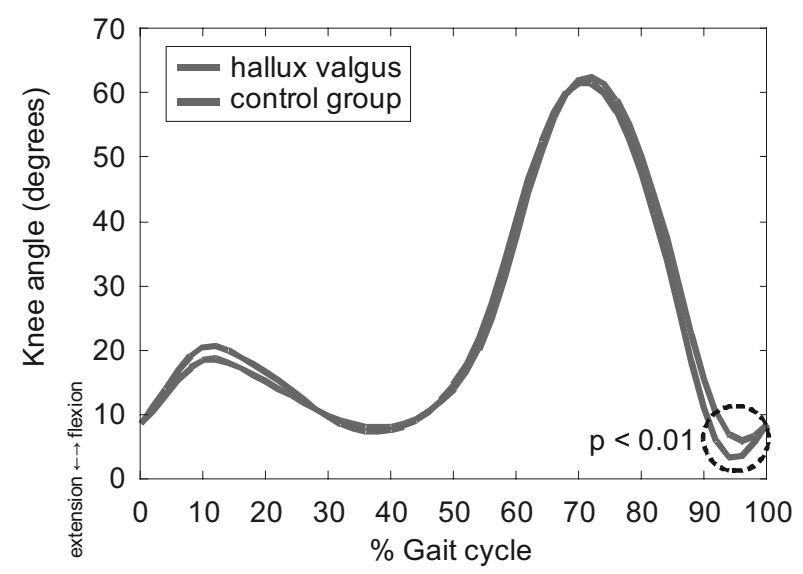

Fig. 3

Hip movement in the frontal plane during gait in people with hallux valgus and the control group

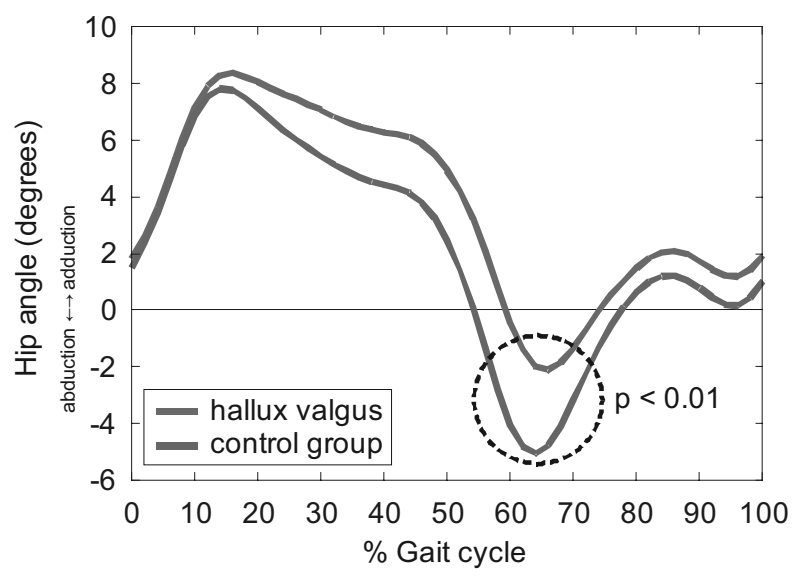

Fig. 4

Pelvis movement in the frontal plane during gait in people with hallux valgus and the control group

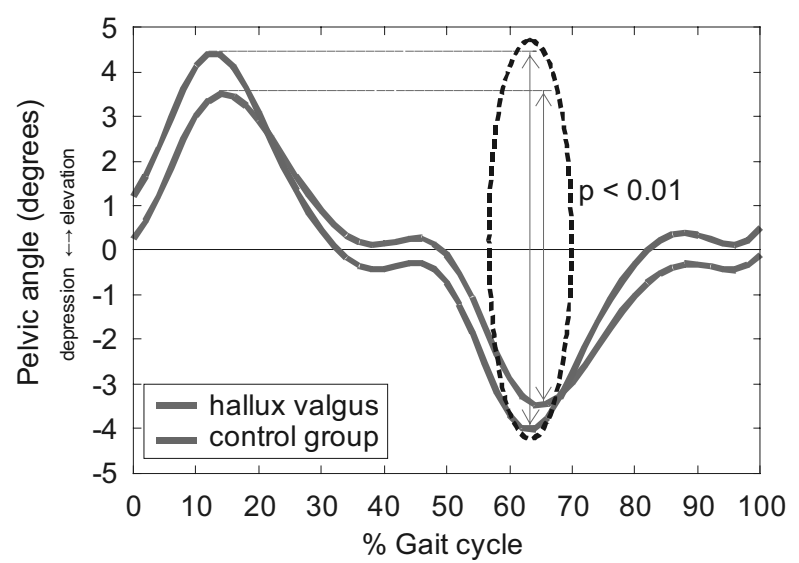

\section{DISCUSSION}

The hallux and the first metatarsophalangeal joint (MTPJ I), together with the plantar aponeurosis, play a major role in loading transmission during gait. Dysfunction of these structures in the case of HV deformity can cause excessive foot pronation (Huang, Kitaoka, An, \& Chao, 1993; Waldecker, 2004), which increases the range of forefoot movement, affects foot stabilization and resupination at the end of the stance phase (Frank, Satake, Robinson, \& Gentchos, 2009). The excessive pronation found by Bolgla and Keskula (2003) represents the most common biomechanical problem and is often cited as a key contributor in many overuse injuries of the lower limb and lower back. Excessive pronation, according to Dinsdale (2009), is synonymous with excessive calcaneal eversion and increased internal tibial rotation. Root, Orien, and Weed (1977) reported 
that abnormal subtalar joint pronation can be a result of forefoot varus, rearfoot varus, tibia vara, ankle joint equinus and a plantar flexed first ray.

Our results confirm that $\mathrm{HV}$ deformity influences the movement of the whole lower extremity and pelvis during gait. The greater plantar flexion at the beginning of the stance phase was also found in subjects with juvenile HV (Janura et al., 2008). The smaller dorsiflexion during the stance phase corresponds to the results of the $3 \mathrm{D}$ gait analyses using the multisegment foot model in subjects with HV (Deschamps, Birch, Desloovere, \& Matricali, 2010; Hwang et al., 2006).

Glasoe, Nuckley, and Ludewig (2010) found that people with HV had an increased range of adduction during mid-swing at the forefoot-rearfoot angle and a decreased inversion, whereas during the pre-swing phase, a significantly increased rearfoot eversion was found. These changes in the frontal plane movement of the foot can relate to lesser hip abduction during preswing in our experimental group. For an optimal performance of the toe off, dorsiflexion in MTPJ I within the range of 65 degrees is necessary. The physiological range of the hallux dorsiflexion is from 20 to 30 degrees; the plantar flexion of the first metatarsal compensates for the missing 40 degrees. The excessive pronation of the foot does not influence the required dorsiflexion in MTPJ I (Frank et al., 2009). Similarly, in functional hallux limitus, extension of the MTPJ I during weightbearing is not possible. According to Dinsdale (2009) the limited plantar flexion of the first ray compensates for the disturbed stabilization of the first metatarsal against the ground, owing to excessive pronation or delayed resupination. This condition is known as "sagittal plane blockage". Sagittal plane blockage can, according to Danaberg (1993a, 1993b) and Dananberg and Guiliano (1999), cause and perpetuate many chronic postural complaints, which include lumbar stress and chronic low back pain.

Dimonte and Light (1982) reported that the patients with HV will tend to keep their weight on the lateral border of the foot. The propulsion cannot be made optimally in cases of HV. Patients with HV have to use apropulsive gait. Apropulsive gait could explain the smaller degree of hip abduction at the toe off, which we found in our experimental group as well.

Our experimental group used a lesser range of pelvis obliquity and pelvis rotation as compared to the CG. Dinsdale (2009) reported that the foot should be stable to ensure quality support during the stance phase. The failure of foot stabilization due to forefoot dysfunction disrupts the function of muscles stabilizing the pelvis. Over time these muscles become, according to Dinsdale (2009), fatigued, weak, hypotonic and tender upon palpation. This often leads to abnormal pelvic movement, pelvic muscle imbalance and pelvic instability. Dananberg (1993a, 1993b) found the relationship between a common, but rarely recognized entity known as "functional hallux limitus" and chronic postural complaints, including lumbar stress and chronic low back pain. The lesser range of pelvis motion can be also related to a reduced walking speed and a shorter stride length, which was demonstrated in other studies of the gait in subjects with HV (Khazzam, Long, Marks, \& Harris, 2007; Menz \& Lord, 2005).

\section{CONCLUSIONS}

This study demonstrated that HV does not exclusively concern the foot. The centralization and stabilization failure of the first metatarsophalangeal joint does not allow patients with hallux valgus deformity to perform heel off and toe off optimally. It can be especially negatively projected at the end of a pre-swing phase during walking. The valgus deformity of the big toe can negatively influence function of the lower extremities and can cause overloading of those segments as well.

\section{ACKNOWLEDGEMENT}

The study has been supported by the research grant from the Ministry of Education, Youth and Sports of the Czech Republic (No. MSM 6198959221) "Physical Activity and Inactivity of the Inhabitants of the Czech Republic in the Context of Behavioral Changes" and by the research grant from the Grant Competition at Palacký University in Olomouc (FTK_2010_017).

\section{REFERENCES}

Blomgren, M., Turan, I., \& Agadir, M. (1991). Gait analysis in hallux valgus. J. Foot Surg. 30(1), 70-71.

Bolgla, L. A., \& Keskula, D. R. (2003). A biomechanical approach to evaluating and treating lower leg dysfunction. Journal of Athletic Therapy Today, 8(5), 6-12.

Bryant, A., Tinley, P., \& Singer, K. (1999). Plantar pressure distribution in normal, hallux valgus and hallux limitus feet. The Foot, 9(3), 115-119.

Bryant, A., Tinley, P., \& Singer, K. (2000). Radiographic measurements and plantar pressure distribution in normal, hallux valgus and hallux limitus feet. The Foot, 10(1), 18-22.

Cohen, J. (1988). Statistical power analysis for the behavorial sciences (2nd ed.). New York: Routledge Academic.

Dananberg, H. J. (1993a). Gait style as an etiology to chronic postural pain. Part I. Functional hallux limitus. Journal of the American Podiatric Medical Association, 83(8), 433. 
Dananberg, H. J. (1993b). Gait style as an etiology to chronic postural pain. Part II. Postural compensatory process. Journal of the American Podiatric Medical Association, 83(11), 615.

Dananberg, H. J., \& Guiliano, M. (1999). Chronic low back pain and its response to custom made foot orthoses. Journal of the American Podiatric Medical Association, 89(3), 109.

Deschamps, K., Birch, I., Desloovere, K., \& Matricali, G. A. (2010). The impact of hallux valgus on foot kinematics: A cross sectional, comparative study. Gait \& Posture, 32(1), 102-106.

Dimonte, P., \& Light, H. (1982). Pathomechanics, gait deviations, and treatment of the rheumatoid foot: A clinical report. Phys. Ther., 62(8), 1148-1156.

Dinsdale, N. (2009). How abnormal foot motion can be a major contributor to lower back and pelvic problems. SportEX dynamics, 19, 11-14.

Frank, C. J., Satake, N., Robinson, D. E., \& Gentchos, C. E. (2009). Hallux Valgus. Retrieved 30. 9. 2009 from the World Wide Web: http://emedicine.medscape.com/article/1232902-overview

Glasoe, W. M., Nuckley, D. J., \& Ludewig, P. M. (2010). Hallux Valgus and the first metatarsal arch segment: A theoretical biomechanical perspective. Physical Therapy, 90(1), 110.

Halebian, J. D., \& Gaines, S. S. (1983). Juvenile hallux valgus. J. Foot Surg., 22(4), 290-293.

Huang, C. K., Kitaoka, H. B., An, K. N., \& Chao, E. Y. (1993). Biomechanical evaluation of longitudinal arch stability. Foot Ankle, 14(6), 353-357.

Hughes, J., Clark, P., \& Klenerman, L. (1990). The importance of the toes in walking. J. Bone Joint Surg. Br., 72(2), 245-251.

Hwang, S., Choi, H., Lee, K., \& Kim, Y. (2006). 3D motion analysis on the Hallux Valgus by using the multisegment foot model. Key Engineering Materials, 321, 988-991.

Janura, M., Cabell, L., Svoboda, Z., Kozáková, J., \& Gregorková, A. (2008). Kinematic analysis of gait in patients with juvenile Hallux Valgus deformity. Journal of Biomechanical Science and Engineering, 3(3), 390-398.

Khazzam, M., Long, J. T., Marks, R. M., \& Harris, G. F. (2007). Kinematic changes of the foot and ankle in patients with systemic rheumatoid arthritis and forefoot deformity. J. Orthop. Res., 25(3), 319-329.

Kolář, P. (2001). Systematizace svalových dysbalancí z pohledu vývojové kineziologie. Rehabilitace a fyzikální lékařství, 8(4), 152-164.

Kučera, M. (1994). Noha - jeden z limitujících faktorů výkonnosti. Med. Sport. Boh. Slov., 3, 114-119.

Lorimer, D., Neale, D., \& French, G. (2006). Neale's disorders of the foot. Edinburgh: Churchill Livingstone.

Martinez-Nova, A., Sanchez-Rodriguez, R., Perez-Soriano, P., Llana-Belloch, S., Leal-Muro, A., \& Pedre-
ra-Zamorano, J. D. (2010). Plantar pressures determinants in mild Hallux Valgus. Gait Posture, 32(3), 425-427.

Menz, H. B., \& Lord, S. R. (2005). Gait instability in older people with hallux valgus. Foot Ankle Int., 26(6), 483-489.

Milani, T. L., \& Retzlaff, S. (1995). Analysis of pressure distribution for the evaluation of gait in patients with hallux valgus surgery. Z. Orthop. Ihre. Grenzgeb, 133(4), 341-346.

Root, M. L., Orien, W. P., \& Weed, J. H. (1977). Normal and abnormal function of the foot (1st ed.). Los Angeles: Clinical Biomechanics Corp.

Torkki, M. (2004). Surgery for hallux valgus: Studies on cost-effectiveness and timing of treatment. Unpublished Doctoral dissertation, University of Helsinki, Helsinki, Finland.

Vařeka, I., \& Vařeková, R. (2003). Klinická typologie nohy. Rehabilitace a fyzikální lékařství, 10(3), 94-102.

Vittas, D., Jansen, E. C., \& Larsen, T. K. (1987). Gait analysis before and after osteotomy for hallux valgus. Foot Ankle, 8(3), 134-136.

Waldecker, U. (2002). Metatarsalgia in hallux valgus deformity: A pedographic analysis. J. Foot Ankle Surg., 41(5), 300-308.

Waldecker, U. (2004). Pedographic analysis of hallux valgus deformity. Foot and Ankle Surgery, 10(3), 121-124.

Yavuz, M., Hetherington, V. J., Botek, G., Hirschman, G. B., Bardsley, L., \& Davis, B. L. (2009). Forefoot plantar shear stress distribution in hallux valgus patients. Gait Posture, 30(2), 257-259.

\section{VLIV VALGÓZNÍ DEFORMITY PALCE NA POHYB PÁNVE A DOLNÍCH KONČETIN PŘI CHŮZI (Souhrn anglického textu)}

VÝCHODISKA: Palec a I. metatarzofalangeální kloub hrají klíčovou úlohu v přenosu zatížení při chůzi.

CÍLE: Účelem této studie bylo analyzovat a interpretovat rozdíly v kinematických parametrech chůze u osob $\mathrm{s}$ hallux valgus v porovnání s kontrolní skupinou.

METODIKA: Porovnávali jsme osoby s asymptomatickou oboustrannou valgózní deformitou palce $(\mathrm{n}=6,57,8 \pm 5,64$ let $) \mathrm{s}$ kontrolní skupinou $(\mathrm{n}=11$, $50,7 \pm 4,41$ let). Provedení chůze jsme analyzovali pomocí optoelektronického systému Vicon MX. Každý proband byl instruován $\mathrm{k}$ chůzi svým přirozeným způsobem i tempem. Vyhodnotili jsme 5 pokusů u každého probanda. Získaná data jsme statisticky zpracovali pomocí párového studentova t-testu. Věcnou významnost jsme vypočitali pomocí koeficientu „effect size“ $\left(\omega^{2}\right)$.

VÝSLEDKY: U osob s HV jsme nalezli statisticky i věcně významně menší maximum dorzální flexe 
$\mathrm{v}$ průběhu stojné fáze $\left(\mathrm{p}<0,01, \omega^{2}>0,06\right)$ a větší maximum plantární flexe na počátku stojné fáze $(\mathrm{p}<0,01$, $\left.\omega^{2}>0,06\right)$. Maximum extenze $\mathrm{v}$ kolenním kloubu bylo osob s HV v závěru švihové fáze u statisticky i věcně významně větší $\left(p<0,01, \omega^{2}>0,06\right)$. Ve frontální rovině jsme pozorovali statisticky i věcně významně menši maximum abdukce $\mathrm{v}$ kyčelním kloubu u osob s HV $\left(\mathrm{p}<0,01, \omega^{2}>0,06\right)$. Rozsah pohybu pánve ve frontální a transverzální rovině byl statisticky i věcně významně menší u osob s HV ( $\left.p<0,05, \omega^{2}>0,06\right)$.

ZÁVĚRY: Výsledky této studie ukazují, že HV nepředstavuje problém pouze $\mathrm{v}$ oblasti nohy. Valgózní deformita palce může negativně ovlivnit funkci všech segmentů dolní končetiny a vést $\mathrm{k}$ jejich přetížení.

Klíčová slova: hallux valgus, chůze, kinematická analýza.

\section{Mgr. Jitka Kozáková}

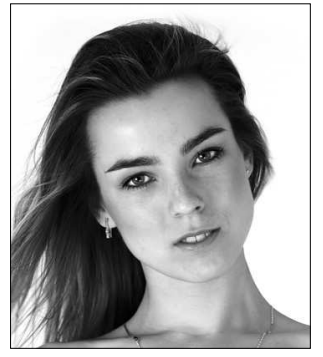

Palacký University, Olomouc

Faculty of Physical Culture

tř. Míru 115

77111 Olomouc

Czech Republic

Education and previous work experience

Faculty of Medicine, Palacký University in Olomouc.

First-line publication

Kozáková, J., Janura, M., Gregorková, A., \& Svoboda, Z. (2010). Hallux valgus z pohledu fyzioterapeuta aneb Je hallux valgus pouze deformita palce? Rehabilitace a fyzikální lékařství, 17(2), 71-77.

Kozáková, J., Janura, M., \& Svoboda, Z. (2009). Může valgózní deformita palce ovlivnit výkonnost vrcholových sportovců? Medicina Sportiva Bohemica et Slovaca, 18(4), 194-195. 